\title{
13. Re-thinking Human Rights and the HIV Epidemic: A Reflection on Power and Goodness
}

\author{
ELIZABETH REID
}

The discourse on human rights in the context of the HIV epidemic has been drawn from a legal paradigm of human rights for which international human rights law provides the theoretical and legal framework. As a result, the HIV and human rights discourse has focused on the ways in which human rights law has been violated in the context of the epidemic. Extensive descriptions of HIVrelated human rights violations in different cultural, economic and political contexts have been documented. These inventories are then used to confront and shame the perpetrators, a classical legal practice and the dominant practice of human rights activism. This chapter upholds the importance of respect for and promotion of human rights in general and in the context of the HIV epidemic. The issue it explores is how best this can be done.

The legalistic approach to human rights and HIV has had positive outcomes. However, neither the confronting of transgression nor the discourse of a human rights based approach to HIV seem to have been as effective as desired in bringing about greater respect, greater dignity or lives less harmed by stigma or blessed with greater wellbeing. Heywood has pointed out some achievements (Heywood 2004). It has resulted in changes in policies and behaviours. In many countries there is now legislation and policy protecting the human rights of people infected/affected by HIV. Human rights arguments have had an impact on global thinking, the conduct of pharmaceutical companies and, in some cases, the practices of governments. However he acknowledges that the degree to which these protections have benefited people is patchy and they have had little tangible impact on the lives of poor women and children. To this list, one should also add men.

The prominence given to the legalistic and violations approach to human rights has meant that little or no work has been done to document and analyse the ways in which HIV-related human rights have been respected and upheld. Early in the epidemic, at the First International Conference on Health and Human 
Rights, held at Harvard University in 1995, those present were challenged by Slobadan Lang, the Professor of Public Health at the University of Zagreb, to develop an activism of praise. He pointed out that, where, as in his region, human rights violations are widespread, a practice of praising those who honour and respect human rights might be developed. This, he argued, would reinforce such behaviour. It provides guiding narratives, accounts of respect and support across difference, of defiant bravery, of quiet resistance.

A practice of praising builds on and strengthens the goodness in people. It is an activism of respect. Respect differs from rights. It is not an entitlement that people have or something that can be claimed. Respect must be earned. An activism of respect and praising gives hope to those who want to live according to the values embedded in human rights. It gives an account of the exercise of responsibility and creates the possibility of collective integrity. Through reinforcing the individual and collective practice of human rights and values, this approach could bring about the benefits and social changes, the lack of which Mark Heywood laments. A practice of praising would also bring a different moral dimension to the legal paradigm. It offers an alternative to its confrontational forms of advocacy and activism.

A further consequence of the practice of the violations approach is that the focus on identifying and confronting transgressions means that less attention is paid to understanding the social and economic conditions which create the violations. Paul Farmer writes: 'The struggle to develop a human rights paradigm is one thing; a searching analysis of the mechanisms and conditions that generate these violations is quite another. Without understanding power and connections, how do we understand why rights are abused?' (2003, 11). Farmer argues that violations of human rights are symptoms of deeper pathologies of power 'linked intimately to the social conditions that so often determine who will suffer abuse and who will be shielded from harm' $(2003,7)$.

The pathologies of power that determine who, amongst those infected, affected or in danger of infection by HIV, will suffer from violations of their rights have not formed a part of the human rights discourse on HIV. The discourses of vulnerability, women's vulnerability to infection, the vulnerability of the marginalised, are power neutral, divorced from the pathologies that create the conditions of vincibility. Nor are these pathologies of power often addressed in HIV programming. The social conditions in which they are embedded and expressed give rise to the abuse of rights but are usually considered to be slow and difficult to change, too slow for the response to the HIV epidemic.

Consider the pathologies of power which shape women's lives within the epidemic. Violence and the fear of violence, rape, incest, bride price, marital subjugation, child brides, death in childbirth, ignorance of one's body and 
sexuality, misogyny, covert HIV testing in pregnancy, the abduction of women, the lack of valuing of women, and more-practices such as these spread the epidemic, assign the duty of care and concern to women, and often constrain women's access to HIV prophylaxis and antiretroviral therapies. They cause untold trauma to women and their children.

The attempts to capture these pathologies in a language of the infringement of women's human rights has often miscarried. Claims of violations of women's rights provoke various responses from men, including: What about our rights? And: Why are we being blamed? Both are reactive and close down dialogue; neither open up the possibility of reflection and growth. Men often experience the discourse on the rights of women as a form of social exclusion resulting in their 'loss of respect and dignity' (Colvin and Robins 2009). Women have been told that these rights violations are difficult if not impossible to address in the timeframe of HIV. What is needed is an understanding of the forces and double standards in a society which are manifested in these pathologies of power, for these are the same forces which drive the HIV epidemic.

An approach to HIV-related social change which, drawing on the work of Paulo Freire, attempts to address these driving forces of the epidemic has been developed. Stephen Lewis has singled it out as 'the stunning revelation of community conversations' (Lewis 2004). In a visit to rural Ethiopia mid-2004, Lewis sat with two communities, listening to them converse about the social conditions which were spreading the epidemic. One conversation involved 200 villagers who had been meeting once a fortnight for a couple of months; the other involved 15 or 20 people, with dozens of onlookers, who had been conversing for more than a year. Both communities were in a predominantly Islamic region.

The community conversation approach draws on traditions of talking things through and collectively deciding how to handle them. Community conversations are structured approaches to helping communities become aware of the ways in which their social norms, values and practices can bring the epidemic into their community, marginalise and humiliate those affected, and lessen the community's capacity to survive the epidemic. The methodologies used to stimulate conversations create a consciousness of these dynamics and then assist the communities in deciding how to respond.

The community conversations approach is based on a theory of social change which posits three areas of focus in building community capacity to change: community understanding of the issues it faces, community knowledge of itself, and community skills for changing. It facilitates conversations structured to assist in bringing about the changes in community norms, values, practices 
and power relations which help create communities in which conflicts can be resolved, in which HIV-affected and other socially marginalised people are supported, and in which the HIV epidemic struggles to gain a foothold.

The subject matters that Lewis heard publicly discussed in these community conversations 'without so much as a touch of embarrassment or shyness' included female genital mutilation, sexual violence, bride sharing, child abduction, early marriages, condoms, living with HIV and women's rights.

The results were astonishing. In one community, where female genital mutilation had been universally practised, it was down to 10 to 15 percent within a year as a result of the understanding gained in these conversations. An Islamic leader and 130 other men decided to be tested for HIV in order to set an example for others. Young girls talked openly about their rights as women and strategies they had adopted to protect themselves from HIV infection. Lewis commented:

It was all quite extraordinary. We talk forever about countries where the level of awareness of HIV is very high but behaviour change is negligible. These community conversations have resulted in huge behaviour change. I have always believed that it would take generations even to show a willingness to address gender equality. Here it seems to have happened virtually overnight! (Lewis 2004)

What makes these community conversations so effective in addressing the pathologies of power? The answer lies in the creation of a structured environment in which communities are able to reflect together upon their norms and practices, inclusive spaces in which all their members - irrespective of gender, age, class, articulateness, status, ethnicity - are able to voice their concerns and opinions, and in which together, as a group, they seek to find ways to change, to protect themselves from the epidemic.

These conversations harness the power for good in a community and build on human potential and human virtues. They acknowledge human frailty without seeking it out to shame or confront. They enable practices of collective integrity and responsibility to arise.

They are, in the words of Michael Ignatieff, a practice of human rights as aspirational. They assume that people aspire to a world in which all human beings are respected, where their persons should be inviolable, and where they have enforceable rights by the very fact of being human beings (Ignatieff 1999). These aspirations are made more possible through the shared spaces of these conversations, spaces which form sanctuaries within which the pathologies of power can be confronted and changed. 
The pathologies of power that determine who, amongst those infected, affected or in danger of being infected by HIV, will suffer from violations of their rights include the norms and practices of communities but encompass a multitude of other offences against human dignity: deprivation, neglect, indifference, racism, unemployment, sexism, corruption, ill-health, illiteracy and under-education. Can these be addressed and changed through methodologies of community 'conscientisation' and empowerment?

Many of these offences are not amenable to community-based problem-solving approaches alone. Their roots lie beyond communities as well as within them. Within communities the roots are found in systems of social relations and cultural practices; within societies, structural violence is embedded in the institutions of the society and economy. In what ways can these structural pathologies be understood and addressed?

We have been reminded recently that, as long ago as 1969, Johan Galtung wrote of the condition of structural violence in which people are denied decent and dignified lives because their basic physical and mental capacities are constrained by hunger, poverty, inequality and exclusion (Galtung 1969; Uvin 1998, Farmer 2004, 307). Structural violence is systemic violence carried out by those belonging to a certain social order. In these situations, neither blame nor praise can be attached to individual actions alone.

Violence of this type is built into the structure and functions of a society. Hence, it manifests itself differently in each society, for it depends on each country's historical, political and cultural circumstances. Structural violence leads to acute violence. Genocide might be its manifestation in Rwanda in 1994 (Uvin 1998), or it might be the violence, aggression and corruption in Papua New Guinea in recent years.

In PNG, there is a rapidly expanding and generalised HIV epidemic; there is a breakdown in law and order; there is the constant threat of violence; increasing numbers of politicians and senior bureaucrats are being named as corrupt. To outside eyes, these are often seen as local tragedies locally derived.

The concept of structural violence helps us see it differently. It traces how inequity is structured and legitimised over time. It renders visible the structural power relations which have contributed to how the present has come to be and who within the present benefit or are debased. It enables the question to be posed: who are the untimely dead? In PNG, these include the women dead in childbirth, the women raped and discarded, those dead of treatable diseases and conditions, the burnt, the children defiled, those killed in ethnic conflict, the 
murdered, and, increasingly, the dead of HIV. These are the victims of structural as well as local violence, those whose human rights have been violated in multiple ways.

Paul Farmer's challenge to undertake a 'searching analysis of the mechanisms and conditions that generate these violations' raises the question of how we understand this world of hostility and degradation. Too often it is 'seen' and understood through the creation of 'the Other'. From the description of what is - brutality, lawlessness, quickness to anger, vengeance, insecurity - an elision is made to They: 'They are a violent people'; 'They have little or no respect for human life'; 'They are rascals and rapists'; and so on. The state of their world is ascribed causally to them. This way of understanding their world justifies the neglect of their human rights. Moral scrutiny focuses narrowly on them rather than encompassing the factors which shape and determine their world and their behaviour.

The concept of structural violence provides us with a way of understanding such violence and lawlessness which refuses the elision from description to the predication of these qualities to people. Rather, anger, despair, frustration, cynicism, normlessness, confrontation are seen as outcomes of deprivation, as manifestations of structural violence, rather than as existential states, ways of being in the world.

The validity of such an analysis is borne out by a study of crime in NSW. A report prepared by the NSW Bureau of Crime Statistics and Research showed that falling crime rates in NSW (12 out of 16 major categories in the two preceding years) can be linked to higher wages among young men and a drop in long-term unemployment. The Director of the Bureau argued: 'Low wages and long-term unemployment are significant contributors to crime. When they improve crime tends to fall' (quoted in Nicholls 2004). Cowboy teaches us that this is as true in Port Moresby as in NSW (McLaren and Stiven 1991).

Historical and political conditions in PNG have created the systems and institutions which create deprivation and dysfunctionality. The social outcomes include a paucity of social mechanisms for dealing with conflict, concepts of women as disposable property, and pervasive and chronic unemployment, especially among young men. These deprivations contribute to the violence, aggression and corruption which fuel the HIV epidemic.

In such a context, it is not difficult to assemble an inventory of human rights transgressions. Nor is the confronting of perpetrators unusual. Practices of blaming, threatening, finger pointing and demands for vengeance are pervasive. 
However, a legalistic approach to human rights in such settings does not create a moral discourse, stimulate the desire for change or craft the courage to speak into the silence of taboos, tradition or allegiance.

How then might human rights be addressed and honoured? Would practices of respect and praising work? Because, in PNG, one's identity, ways of behaving, the borders of one's world are communal rather than individual, it was decided to convene two workshops to critically reflect on approaches to community mobilisation to determine their relevance and possible effectiveness in the context of the HIV epidemic and its driving forces (PNGSDP 2007).

The methodology of community conversations privileges working with groups and communities, builds on the goodness in people and communities, and strengthens social capital. For these reasons, participants at the workshops decided that it should be developed for the PNG context. The community conversations approach resonates with people's view of the PNG way of doing things: community and clan discussion of problems, story telling as a form of moral guidance, a strong sense of reciprocity and of concern for the well being of the group. The methodology strengthens the skills required to understand problems and to look for ways through them: the ability to see and understand the consequences of actions, to make the transition from talking or 'storying' to addressing problems, to resolve differences and tensions in non-violent ways, to experience empathy and concern across differences, to accept responsibility and the hard work of thinking as a collective duty rather acquiescing to traditional or modern forms of knowledge and authority.

As the methodology for PNG was being developed, a pilot phase was begun. Community conversations teams have gathered and been trained in communities across seven provinces. The interest in the work is great. Stories are emerging of women feeling able to talk at community meetings, of communities coming together to talk about problems caused by drug use, of young people re-thinking their brewing and drinking activities, of parents talking to their children, of husbands and wives talking together. It is too early to determine if communities, as well as individuals, will be able in a sustained way to identify and respond to the forces of disharmony, exclusion and deprivation, the pathologies of power, in their midst and to develop the socio-cultural norms, values and practices that create caring and HIV protective communities.

Even if they can, pathologies of power are not only found within communities. They also arise from and cause structural violence. An HIV-related human rights discourse, in this analysis, would encompass social and economic rights such as the right to gainful employment, the right to adequate wages/incomes, to education, to health and more. People have a right not to be systemically and 
chronically deprived of their capacity to lead decent and dignified lives, a right, in Galtung's words, to fulfill to the extent possible their physical and mental capacities.

Such an HIV-related human rights discourse could also encompass a practice of praising. The praise stories could create an understanding of how people resist being overwhelmed by structural and local violations in their society. Such an understanding refuses an analysis in terms of human faults and failings and is open to a belief in human goodness.

A discourse on HIV and human rights which builds on human goodness and integrity could lead to effective approaches to addressing the HIV epidemic and the pathologies of power, local and national, which drive it. It would allow us to aspire to a world where human rights are respected and to an activism of praising, emulating and supporting goodness.

\section{References}

Colvin, Christopher and Steven Robins. 2009. Positive Men in Hard, Neoliberal Times: Engendering Health Citizenship in South Africa. In Gender and HIV/ AIDS: Critical Perspectives from the Developing World, ed. Jelke Boesten and Nana Poku, 187-188. Farnham, UK: Ashgate Publishing.

Farmer, Paul. 2003. Pathologies of Power: Health, Human Rights, and the New War on the Poor. Berkeley: University of California Press.

Farmer, Paul. 2004. An Anthropology of Structural Violence. Current Anthropology 45 (3): 305-317.

Galtung, Johan. 1969. Violence, Peace, and Peace Research. Journal of Peace Research 6:167-91.

Heywood, Mark. 2004. Human Rights and HIV/AIDS in the Context of 3 by 5: Time for New Directions? Canadian HIV/AIDS Policy \& Law Review 9 (2): $6-12$.

Ignatieff, Michael. 1999. Human Rights: the Midlife Crisis. New York Review of Books, May 20. 46 (9).

Lewis, Stephen. 2004. Press Briefing Notes: Recent Trip to Ethiopia. June 1 2004. The Stephen Lewis Foundation. http://www.stephenlewisfoundation. org/news_item.cfm?news=342\&year $=2004$ (accessed 27 April 2010). 
McLaren, Les and Annie Steven. 1991. Cowboy and Maria in Town: Stories of Urban Drift in Papua New Guinea. Australian Film Commission with the assistance of the Australian Broadcasting Corporation and the PNG National Research Institute, Cultural Studies Division.

Nicholls, Sean. 2004. Crime Linked to Economy. Sydney Morning Herald, 23 November 2004.

PNGSDP (PNG Sustainable Development Program) 2007. Report of the Learning Workshops on Strengthening Community Engagement with the HIV Epidemic and its Driving Forces. http://www.pngsdp.com/images/ documents/cci_learning_workshop.pdf (accessed 27 April 2010).

Uvin, Peter. 1998. Aiding Violence: The Development Enterprise in Rwanda. Connecticut: Kumarian Press. 